\title{
Elsterian ice sheet dynamics in a topographically varied area (southern part of the Racibórz-Oświęcim Basin and its vicinity, southern Poland)
}

\author{
Tomasz SALAMON ${ }^{1, *}$
}

1 University of Silesia in Katowice, Faculty of Earth Science, Będzińska 60, 41-200 Sosnowiec, Poland

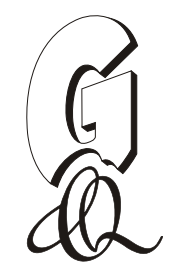

Salamon, T., 2017. Elsterian ice sheet dynamics in a topographically varied area (southern part of the Racibórz-Oświęcim Basin and its vicinity, southern Poland). Geological Quarterly, 61 (2): 465-479, doi: 10.7306/gq.1350

During the Elsterian Glaciation, the Scandinavian Ice Sheet, before reaching its maximum extent, advanced over the mountainous foreland of Southern Poland, which was characterized by a substrate of increasingly varied relief. One such area was the hilly Rybnik Plateau of the southern part of the Racibórz-Oświęcim Basin, located directly north of the Ostrava Basin and Moravian Gate, where the ice sheet advanced far south and formed a large lobe. In this study, till from the Łaziska site, located in southern part of the Rybnik Plateau, was analysed and interpreted. The till was deposited at the top of an W-E oriented ridge composed of Neogene clays. The study indicates that a high basal water pressure occurred at the base of the ice sheet, favouring a basal mechanism of ice sheet movement. Till fabric and kinematic structures indicate that ice flowed easily from the west over the ridge, parallel to its axis. Reconstructed patterns of ice flow direction reflect an ice sheet that was characterized by a strong spatially varied dynamics. The Odra Valley was the main corridor of fast flowing ice to the Ostrava Basin, from where ice was distributed radially in different directions. The second corridor of actively flowing ice was probably located in the Ruda palaeovalley to the north of the Rybnik Plateau. In the central part of the Rybnik Plateau, ice flow was restricted. This less dynamic ice sheet behaviour resulted mostly from the much higher location of the area. This study indicates that the large morphological and lithological variations of the ice sheet substrate induced varied frictional resistance, producing a spatially varied stress field within the ice sheet. This generated active zones of streaming ice adjacent to more passive zones. Potential switching between neighbouring active zones transporting ice towards the ice sheet margin is postulated.

Key words: ice sheet dynamics, fore-mountain area, subglacial till, Elsterian Glaciation, Ostrava Basin.

\section{INTRODUCTION}

Although the Scandinavian Ice Sheet reached its greatest extent in Central Europe during the Elsterian (Sanian) Glaciation (Mojski, 2005), relatively little is known about its glaciological characteristics and dynamics. This is due to the fact that deposits of the Elsterian Glaciation are obscured by overlying younger deposits, and appear on the surface only locally, mainly in the foreland of the Sudetes and Carpathian mountains of southern Poland. Two Elsterian till units were described from the Sudetes foreland (Krzyszowski and Ibek, 1996; Badura and Przybylski, 1998; Krzyszkowski and Karanter, 2001). The Saalian till is understood to have a similar extent. Therefore, differentiating tills of different glaciations from each other is at times problematic (cf. Czubla, 2013). This problem does not exist at the Carpathian foreland, where tills are known from a few sites of the Sandomierz Basin, the Racibórz-Oświęcim Basin and the Carpathian Foothills (Klimaszewski, 1952; Jahn, 1952; Wojtanowicz, 1985; Butrym et al., 1988; Lewandowski, 1988;

*E-mail: tomasz.salamon@us.edu.pl

Received: December 16, 2016; accepted: February 7, 2017; first published online: March 14, 2017
Nitychoruk, 1991; Łanczont, 1997; Wójcik, 2003; Wójcik et al., 2004; Salamon and Wójcik, 2010; Salamon, 2014b, 2016a). These tills are generally correlated with one glaciation, although different opinions exist about their age, i.e. Sanian II (Marine Isotope Stage 12) or Sanian I (MIS 16) have been proposed (cf. Lindner, 2001; Marks, 2005; Mojski, 2005). All of these studies are mainly concerned with issues of stratigraphy and of regional palaeogeography. Detailed sedimentological analyses of the till and interpretation of subglacial conditions have only rarely been undertaken (e.g., Salamon, 2016a).

This paper deals with the Łaziska site, which provides information on the dynamics of the marginal part of the Scandinavian Ice Sheet during the Elsterian Glaciation, at the westernmost part of the Carpathian foreland (Fig. 1). The site is located at the southernmost sector of the Racibórz Basin, in the region of the Rybnik Plateau. The location of the site is specific, lying directly north from the Moravian Gate, i.e. the morphological depression separating the Sudetes and Carpathian Mountains, where a large topographically-controlled lobe formed (cf. Macoun and Králík, 1995; Růžička, 2004; Mojski, 2005). Therefore, the study site can provide important information about the ice behaviour and its spatial distribution within the entire Moravian Gate, where the ice sheet was characterized by many oscillations (Macoun and Králík, 1995; Rủžička, 2004; Nyvlt et al., 2011). Prior to reaching the margin of the mountains, the ice sheet advanced over a substrate of increasingly varied relief 


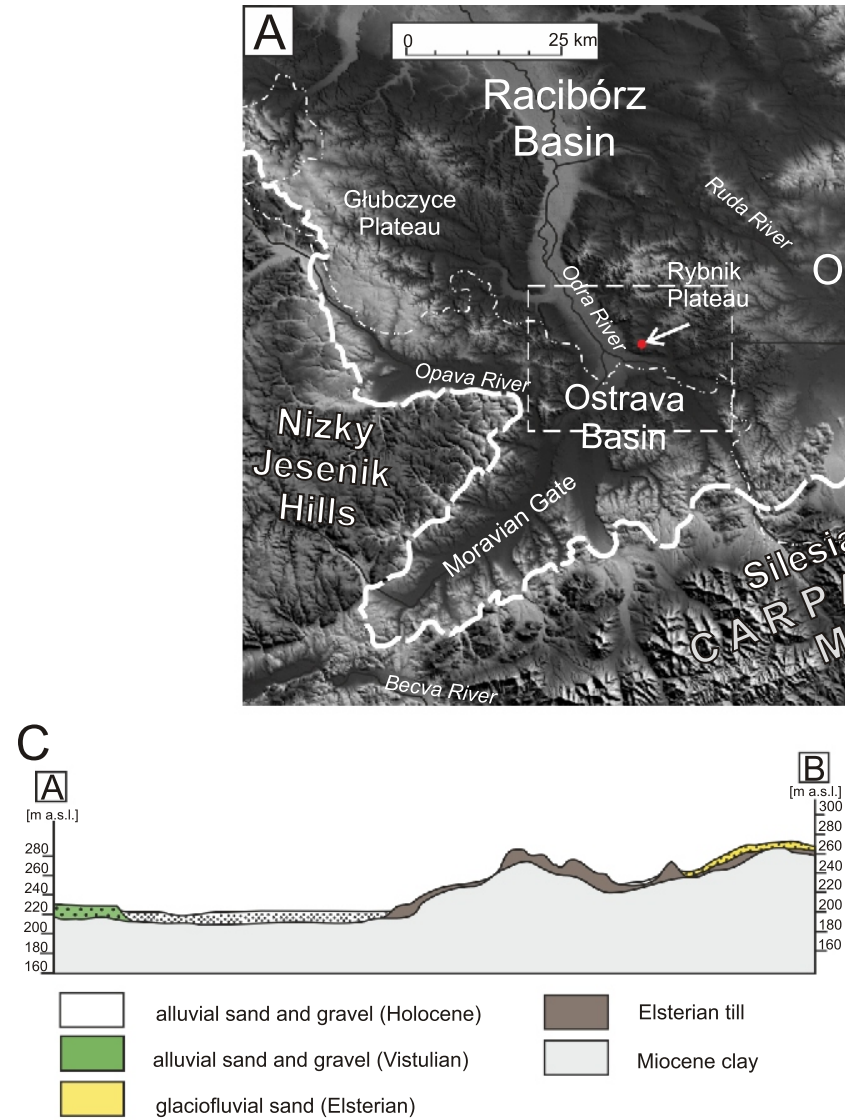

D

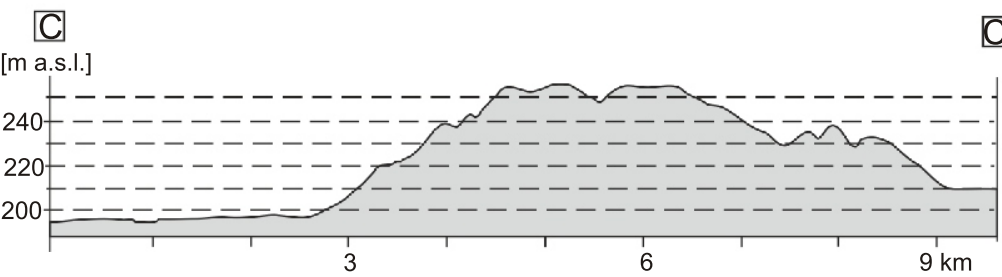

Fig. 1A - location of the study area and extent of the Scandinavian Ice Sheet during the Elsterian Glaciation (white dashed line) based on Mojski (2005); B - relief map of the immediate area of the Kaziska site; C - simplified geological cross-section through the Odra Valley and southern part of the Rybnik Plateau (based on Drozd and Trzepla, 2006); D - morphological profile of the ridge studied

and lithology, which must have significantly affected the ice flow (cf. Salamon, 2016a). At the Łaziska site the till was deposited over Miocene clay. This type of ice sheet substrate was typical of a large part of the Rybnik Plateau.

The purpose of this article is: (a) to define and interpret the sedimentary and structural characteristics of the till within the Łaziska site, (b) to identify subglacial conditions in the area of the southern part of the Rybnik Plateau, (c) to reconstruct ice flow directions within the ice sheet, (d) to determine the relationship between ice flow and the topography of the substrate. All these elements help understand the pattern of ice distribution and ice sheet dynamics in the study area. They also provide a broader perspective on the discussion of Pleistocene ice sheet behaviour, particularly in areas with strongly varied substrate relief.

\section{REGIONAL SETTING}

The study area is located in the southern part of the Rybnik Plateau, which constitutes the highest part of the Raci-
bórz-Oświęcim Basin. This area is also noticeably elevated above the adjacent Ostrava Basin to the south, which continues towards the SW into the Moravian Gate (Fig. 1). The Rybnik Plateau is a hilly, upland area reaching over $300 \mathrm{~m}$ a.s.l. and it is dissected by river valleys up to $50 \mathrm{~m}$ deep. Towards the SE, the Racibórz-Oświęcim Basin passes into the Silesian Foothills of increasingly varied topography, and these form the foreland of the Silesian Beskid Mountains (Fig. 1), i.e. one of the ranges of the Western Carpathian Mountains. The axial part of the study region is the Odra Valley, which separates the Rybnik Plateau from the Głubczyce Plateau, the hilly upland of the Eastern Sudetes foreland (Fig. 1A).

The Łaziska site is located in the marginal part of the Rybnik Plateau, a few kilometres to east of the Odra Valley (Fig. 1B). The Rybnik Plateau is bordered to the south by the Olza River Valley, which is a right-bank tributary of the Odra River. Both rivers form the vast alluvial plain of the northern part of the Ostrava Basin. The southern part of the Rybnik Plateau is dissected by the Leśnica River, which flows southwards from the central part of the plateau, and joins with the Olza River 
(Fig. 1B). The southern, W-E oriented section of the interfluve ridge between the Olza and Leśnica valleys (Fig. 1B) reaches a height of 250-260 $\mathrm{m}$ a.s.l. and rises above the Olza valley at a height of approximately $40-50 \mathrm{~m}$ (Fig. 1D). The study site is located on this interfluve ridge. It is situated just north of the axis of the ridge near its top and reaches a height of $255 \mathrm{~m}$ a.s.l.

The Racibórz-Oświęcim Basin is part of a foredeep basin mainly filled with Neogene clay deposits. In the Rybnik Plateau region, these deposits reach a thickness of about 200-300 m and overlie Carboniferous horsts, which locally reach the surface (Kotlicka and Kotlicki, 1979). The interfluve ridge studied is composed of Miocene clay. The hill is covered by a thin layer of Quaternary deposits, mainly comprising glacial till lying directly on the clayey substrate. The till is locally overlain by glaciofluvial sands up to a few metres thick (Fig. 1C).

Only one unit of Elsterian till was recognized in the central and eastern parts of the Rybnik Plateau (Karaś-Brzozowska, 1963; Klimek, 1972; Lewandowski, 1988). Glaciotectonically deformed moraine ridges, which occur in the adjacent southern part of the Głubczyce Plateau (Opava Hilly Land in the Czech Republic) to the west, record a few ice-marginal oscillations (Macoun and Králík, 1995; Nyvlt et al., 2011). In the Eastern Sudeten Mountains, Elsterian till was observed at a height of over 380 m (Hanáček and Nývlt, 2009). This till is found at similar heights in the Silesian Foothills (Salamon, 2014b). The Odra Valley and Głubczyce Plateau together with the northern part of the Ostrava Basin were also covered by an ice sheet during the Saalian glaciation (Lewandowski 1988; Macoun and Králík 1995; Badura and Przybylski, 2001; Růžička, 2004; Nyvlt et al. 2011; Tyráček, 2011; Salamon 2014a, 2015a, 2016b).

\section{METHODS}

The Łaziska site was exposed for a short time as a result of work related to the construction of the A1 motorway. The sedimentological and structural features of the till and underlying clayey deposits of the substrate were investigated in detail. The investigations included analyses of lithofacies properties, till fabrics, orientation of kinematic structures, and till petrography. Clast macrofabric data were collected by measuring the orientations (strike and dip directions) of the a-axes of at least 30 elongated pebbles with a minimum a-axis of $1 \mathrm{~cm}$ and an $\mathrm{a}$-axis/b-axis ratio of at least 1.5 . The samples were measured at vertical intervals of 20 to $30 \mathrm{~cm}$. The results are shown as rose, contour and point diagrams, which are based on the Schmidt equal-area grid developed with the StereoNet program. The eigenvalues $\left(S_{1}\right.$ and $\left.S_{3}\right)$ and eigenvector $(v)$ were calculated for each sample (Mark, 1973, 1974). Analyses of till petrography were performed on samples of at least 300 particles ranging from 5 to $10 \mathrm{~mm}$ in diameter.

\section{RESULTS}

\section{ŁAZISKA SITE}

The deposits were exposed in the two opposite walls of the excavation for the motorway, with heights of $6-8 \mathrm{~m}$ and lengths of $150 \mathrm{~m}$. Two separate units of Quaternary deposits resting directly on Neogene clays were distinguished (Figs. 2 and $3 \mathrm{~A}$ ), the lower of which, a till, is overlain by glaciofluvial sands. The latter are locally intercalated or overlain by diamictic deposits (Fig. 2).

\section{DEPOSITS OF THE SUBSTRATE}

The glacial deposits are underlain by Neogene clay - silty clay or rarely, clayey silt and silt (Figs. 3 and 4). The exposure displays a $1.5 \mathrm{~m}$ thick upper section of the substrate deposits. These fine-grained deposits vary in colour from blue to grey. Their primary lamination is poorly preserved. This is because the sedimentary structure is usually obliterated by a deformation structure of a breccia type. The deposits are broken into subangular fragments ranging in size from a few to several millimetres, locally a few centimetres (Fig. 3C, D). Due to the generally poor exposure of the clays, the thickness of the layer with deformations is not known. In some places the breccia structure was observed to a depth of at least $1 \mathrm{~m}$. The breccia structure occurs especially within the clay, and is less common within the silty sediments, which are mostly homogeneous (Fig. 3E). Individual shear planes, or sets of small, usually subhorizontal or slightly irregular shear planes, a few centimetres to a few decimetres in length, are superimposed on the breccia structure (Fig. 3C). Longer and more regular subhorizontal shear planes spaced a few centimetres apart are also present locally (Fig. 4B). This is not a sedimentary feature, though some shear planes may have initiated along the contacts of poorly developed laminae. Large shear planes several metres long were also observed in a few places. Some of these structures are inclined and in contact with the lower surface of the diamicton (Figs. 3D and 4A). The inclination of these large shear planes diminishes progressively to a subhorizontal position in a W/NW direction.

Small concentrations of dispersed gravel clasts, and more rarely, small lenses of sandy gravels occur locally within the deposits underlying the till (Fig. 4C). The gravel clasts are usually 2 to $6 \mathrm{~cm}$ (the largest one $>15 \mathrm{~cm}$ ) in diameter and are usually well rounded. Quartz clasts are dominant with minor amounts of local sandstones and mudstones. Scandinavian rocks were not observed.

\section{DIAMICTON}

The till, 2.5-4 m thick, rests on a clayey substrate (Fig. 3A, B). This is a silty-sandy diamicton with a small gravel content. The diamicton is mostly dark grey in colour, except its uppermost part, which is rusty in colour. The lower boundary of the diamicton is slightly undulating or flat (Fig. 3A). Contact of the diamicton with the underlying deposits is generally sharp but locally it is gradational, especially where the diamicton overlies silty deposits (Fig. 4C, D). Three units were distinguished in the diamicton. Boundaries between successive units are gradational (Fig. 2).

The lower unit 1 of the diamicton is up to $1 \mathrm{~m}$ thick and occurs locally. The most important feature of this unit is numerous inclusions of silt or silty clay. They form subhorizontal or slightly inclined laminae, mostly from 1 to $20 \mathrm{~cm}$ thick and from a few decimetres to $>30 \mathrm{~m}$ long (Fig. 4C). Locally, laminae are very thin and reach only a few millimetres in thickness. The infilling sediments are macroscopically massive and homogeneous. These laminae form strongly attenuated folds of sediment incorporated into the diamicton from the substrate. Many of them represent folds completely detached from the substrate, but in several places rooted folds also occur (Fig. 4C, D). In several places unit 1 displays large inclusions of poorly sorted sands and gravelly sands (Fig. 4F). These occur in both walls of the excavation, and are spaced between 30-60 m apart. Inclusions 

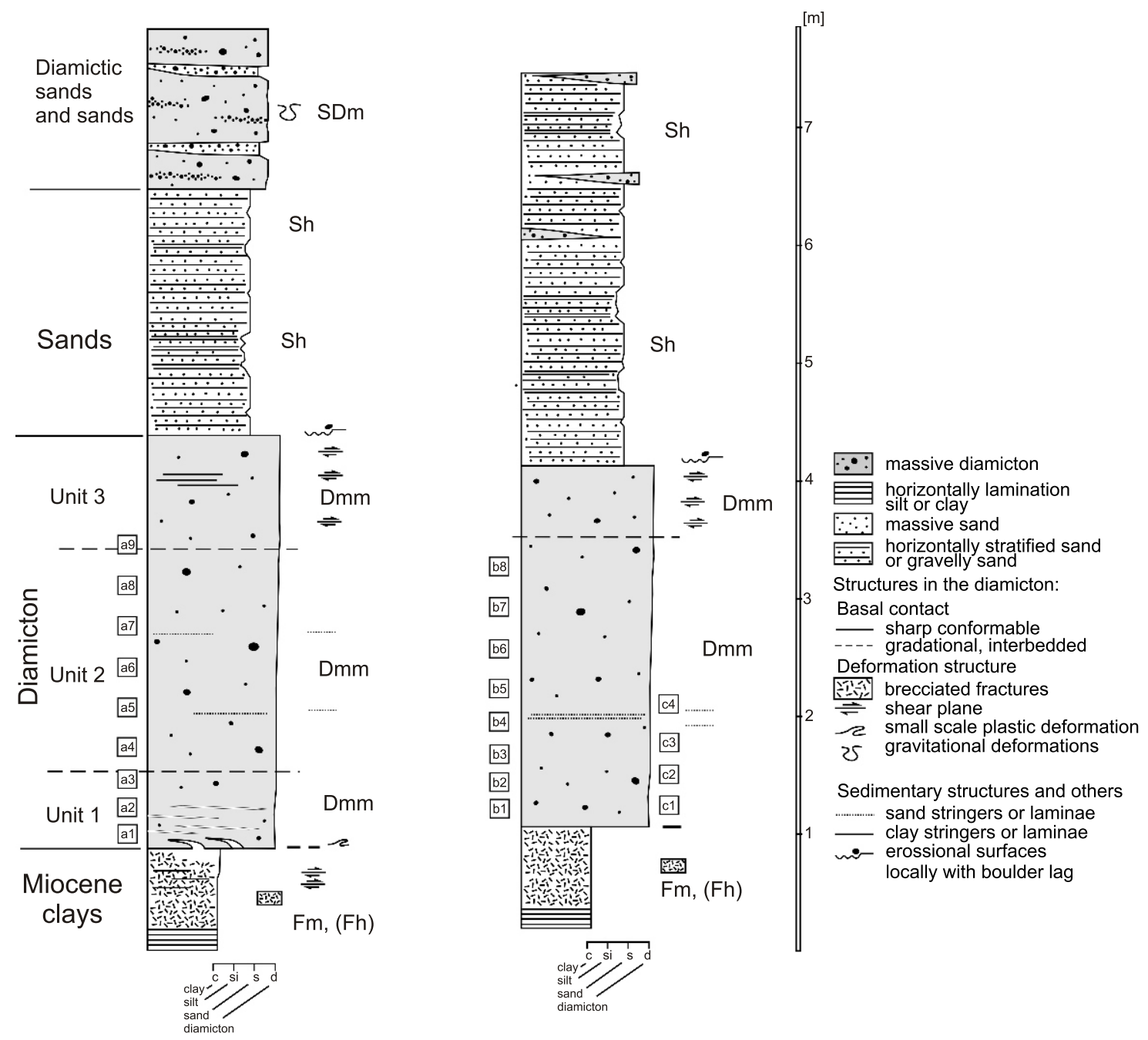

Fig. 2. Schematic sedimentary logs of the Quaternary succession at the Łaziska site

Lithofacies codes based on Eyles et al. (1983): Dmm - diamicton, matrix-supported, massive; Sh, SGh — sand, gravelly sand, horizontal stratified; Fh — clay, horizontally laminated; Fm — clay, massive

occur within the basal part of the diamicton or at the contact of the diamicton with underlying clay. The inclusions form irregular sediment bodies with a lateral extent from 3 to $6 \mathrm{~m}$ and a thickness from 0.3 to $0.8 \mathrm{~m}$. The infilling sediments are usually deformed, although the scale of deformation varies. As a result, their original sedimentary structure is poorly preserved. The infilling sediments are usually massive, sandy gravels in the lower part, and sands in the upper part. Fold deformations with superimposed brittle deformations, i.e. numerous subhorizontal or slightly inclined shear planes, are present within the sediments of the inclusions (Fig. 4F). Above these inclusions, thin intercalations of silty clays from the substrate occur locally within the diamicton (Fig. 4F). The diamicton of unit 1 locally reveals a laminar structure, especially near deformation structures, but most often the diamicton is massive. Numerous fragments of Neogene wood occur in the diamicton. These are usually small, but reach up to $30 \mathrm{~cm}$ long in the case of the largest elongated fragment which occurs in the lower part of unit 1, and is inclined towards the west at a angle of $\sim 30^{\circ}$. Its locally polished surface displays a few sets of small cross-cutting grooves (Fig. 4E).

Unit 2 is $2-3 \mathrm{~m}$ thick and comprises most of the till thickness (Fig. 2). This is mostly a massive, homogeneous diamicton. It contains infrequent laminar inclusions of sand (Fig. 4G). The longest laminae continue for a distance of at least $20 \mathrm{~m}$. Sandy laminae only locally reveal small deformation structures in the form of small inclined folds or faults (Fig. 4H). Individual subhorizontal stringers of sand a few millimetres thick and up to $1 \mathrm{~m}$ long were also observed in the diamicton in a few other places (Fig. 3E).

Unit 3 is $0.5-1 \mathrm{~m}$ thick and comprises the upper part of the diamicton. Locally, the lower part of the diamicton of unit 3 is laminar; silty-clayey laminae, a few millimetres to $3 \mathrm{~cm}$ in thickness, occur alternately with diamictic laminae (Fig. 5A, B). The silty clay is brecciated and its primary structure is not preserved. The unit contains also numerous, variously oriented sets of shear planes and fissures. The most common are subhorizontal shear planes. However, locally these are accompanied by inclined structures. Some of the shear planes are at least a few metres in length. The upper surface of the diamicton is eroded and locally covered with a thin gravel lag.

The gravel fraction of the till is petrographically dominated by quartz $(>40 \%)$. The second most common group constitutes different types of local sandstones ( $25 \%)$. Also important are local wood fragments (8\%). Northern (Scandinavian and the Baltic depression) rocks occur in small frequencies (crystalline rocks $8 \%$, sandstones $10 \%$, limestones $2 \%$ ). 

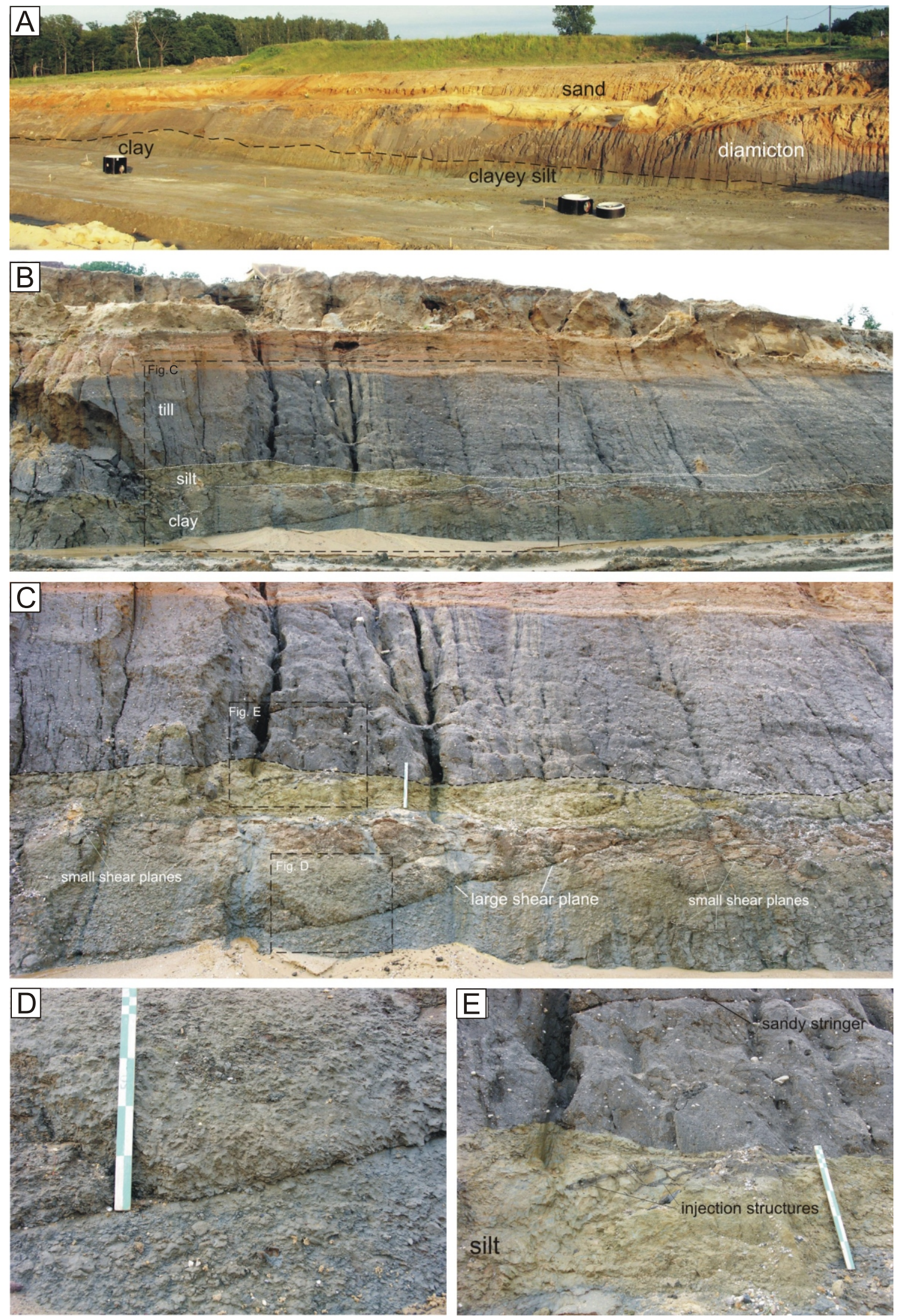

Fig. 3A - overall view of the SE escarpment of the Łaziska site; B, C - diamicton resting on Miocene, mostly clayey substrate at the NW escarpment of the site; D - closer view of the clays with distinct breccia structure and superimposed inclined large shear plane; E - closer view of massive silts directly underlying the diamicton

B - in the central part a $0.5 \mathrm{~m}$ thick layer of massive silt occurs above the clay, the thickness of silts successively diminished towards the right, silts continue and die out within the lower part of the diamicton; $\mathbf{C}$ - multiple generations of deformation are visible within the deposits underlying the diamicton, especially within the clay, a set of shear planes are locally superimposed on the breccia structure; $\mathbf{E}$ - small diamictic wedges are visible within the silts, they are inclined towards the NW and fragmented, the individual fragments are displaced relative to each other along a few small faults 

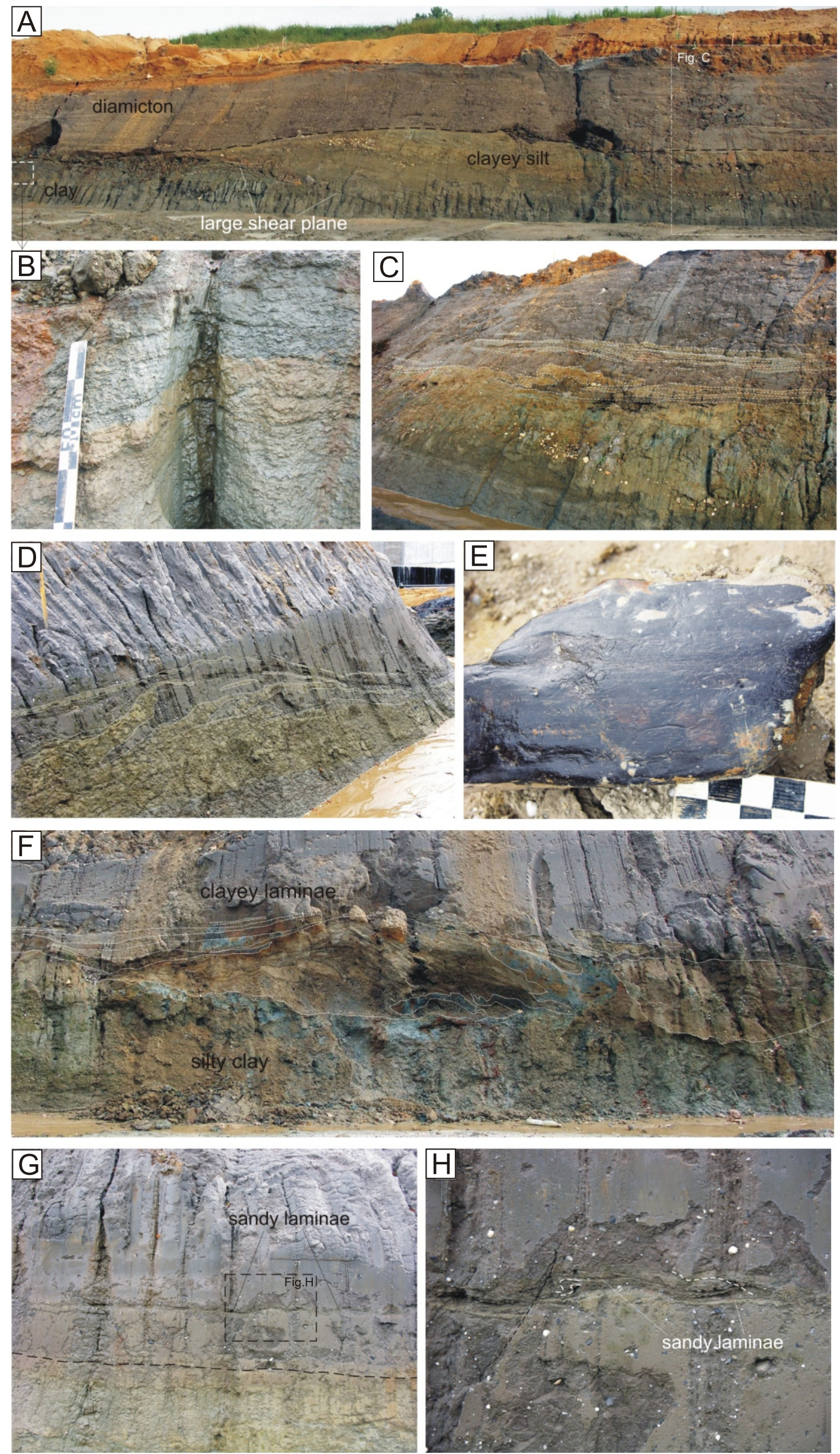

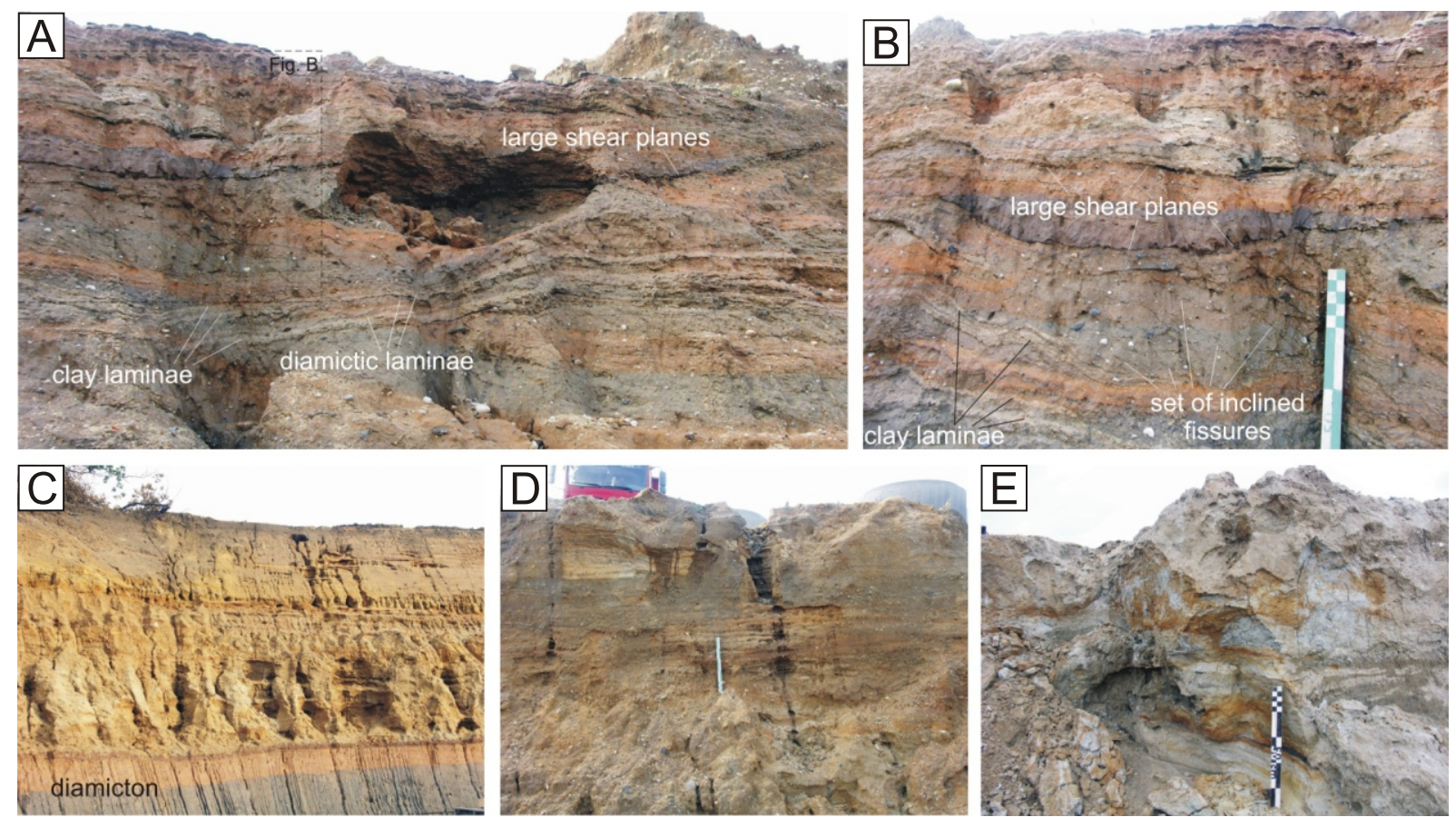

Fig. 5A, B - Upper till unit. Note thin alternating laminae of clay and diamicton within the lower part and numerous brittle deformation structures with dominant subhorizontal shear planes; $C-E$ - deposits overlying the diamicton. These are mainly poorly sorted sands and gravelly sands with horizontal stratification (C, D). At $(E)$ a package of diamictic deposits, which locally overlies the sands, is visible

MACROFABRIC

Macrofabric analyses were carried out in the three profiles (Fig. 6). Eight and nine samples were measured respectively in profiles $A$ and $B$, and 4 in profile $C$. The clast alignments generally indicate high fabric strength shown by high eigenvalues $S_{1}$, which usually reach values in the range of $0.7-0.8$ and, in some cases, even greater than 0.9. Exceptions were found in two samples of the lower part of profile $A$, in which the $S_{1}$ eigenvalues are distinctly lower and range from $0.65-0.67$. The $S_{3}$ eigenvalues are low, ranging from 0.01-0.07. Clast alignment is mostly bimodal, rarely unimodal. It can be assumed that the $S_{1}$ and $S_{3}$ eigenvalues are almost constant throughout the whole profile of the diamicton. The same applies to the azimuths of the mean vectors, which vary within a very small range and indicate a main stress direction from W/WNW to E/ESE.

\section{KINEMATIC STRUCTURE ORIENTATION}

Plastic and brittle kinematic structures, which occur mainly within the lower part of the diamicton, at the diamicton/clay contact and within the clays of the substrate, were measured. These are mostly strongly attenuated, inclined or recumbent folds. All the structures analysed are characterized by a E/ESE conver- gence, so their orientations are consistent with the clast fabric (Fig. 6). The inclinations of large shear planes within the clays underlying the till indicate a dip towards the W/NW (Fig. 3C). Thus, they show also the same directions of principal stress.

\section{INTERPRETATION}

The tabular shape, a large lateral continuity, the presence of Scandinavian material and numerous structural features, such as recumbent folds and shear planes, indicate that the diamicton resting on the Miocene clays is a basal till. The largely obliterated primary structure of the underlying clays suggests that the deposits of the substrate were deformed at the ice sheet base. The varied types of deformation and multiple generations of superimposed structures reflect a multi-stage process of deformation with subglacial conditions varying over time. Homogeneous and massive silts or clayey silts, which locally occur directly below the diamicton and are engaged in fold structures (Figs. 3B and 4C, D), display a plastic style of deformation. The most common breccia structures, occurring especially within the clays, represent more brittle-plastic sediment behaviour. The strain in this case was distributed among the network of numerous multiple cracks separating the sediments into small subangular fragments, which could rotate relative to

Fig. 4A - the till overlying the clay substrate at the SE escarpment of the site. Note the large shear plane within the clay; B - distinct subhorizontal shear planes superimposed on breccia structures; C, D - transitional lower contact of the diamicton. Numerous folds of clayey silts incorporated into the diamicton are visible; E - large fragment of wood excavated from the lower part of the diamicton. Note numerous cross-cutting grooves on its surface; F - deformed inclusion of gravelly sandy deposits at the diamicton/clay contact. Ductile and brittle deformation structures are visible within the inclusion, which is composed of two bodies of coarse-grained sediment separated by a silty clay fold incorporated from the substratum. This isoclinal fold indicates vergence towards the E/SE. The smaller recumbent or completely detached folds of silty clay occur locally within the lower part of the inclusion. Clay laminae are present within the diamicton above the inclusion; G - the two most prominent, closely spaced, subhorizontal sandy laminae in the lower part of unit 2; H - rare deformation structures of sandy laminae 

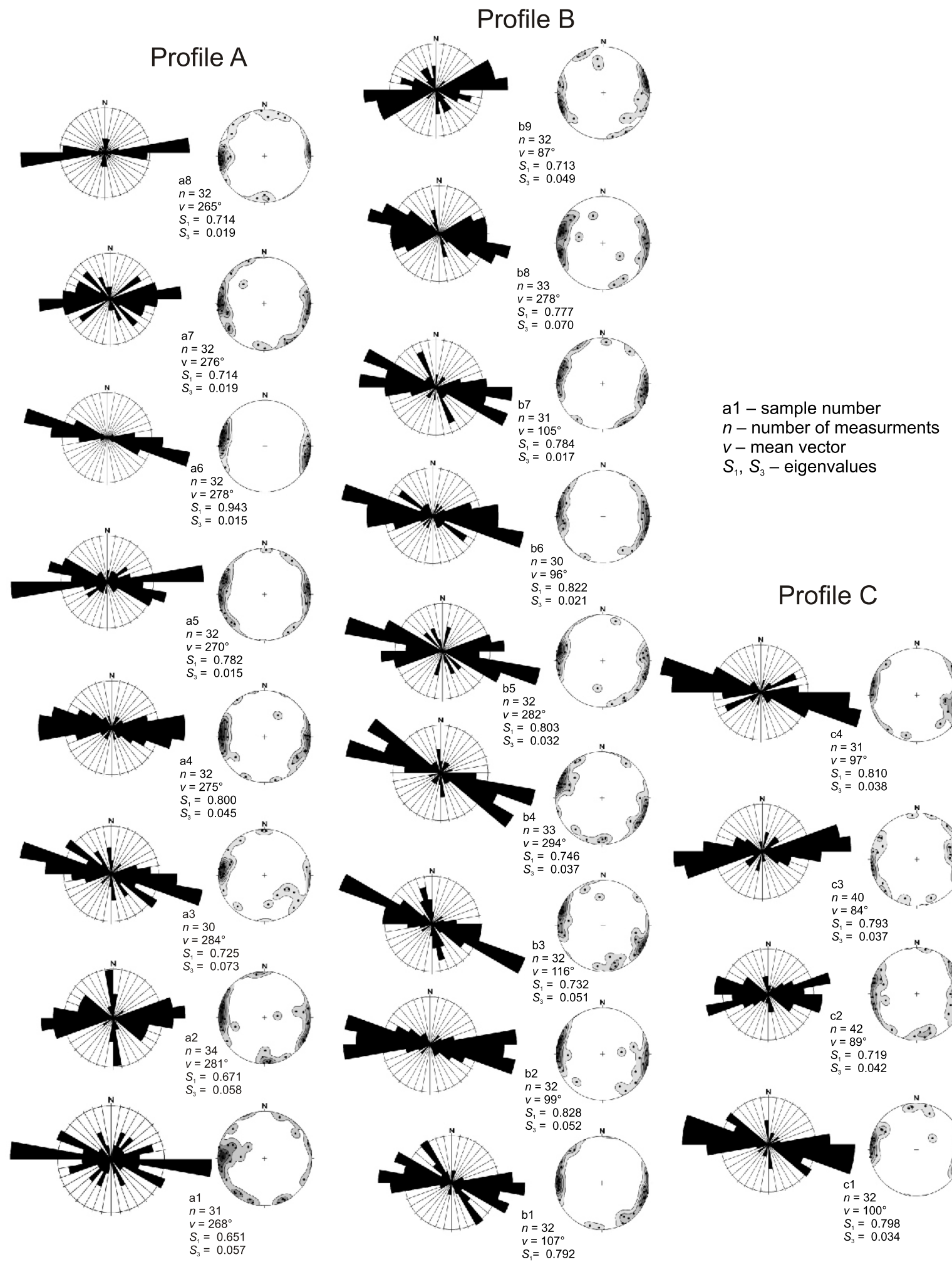

$V-$ mean vector
$S_{1}, S_{3}$ - eigenvalues
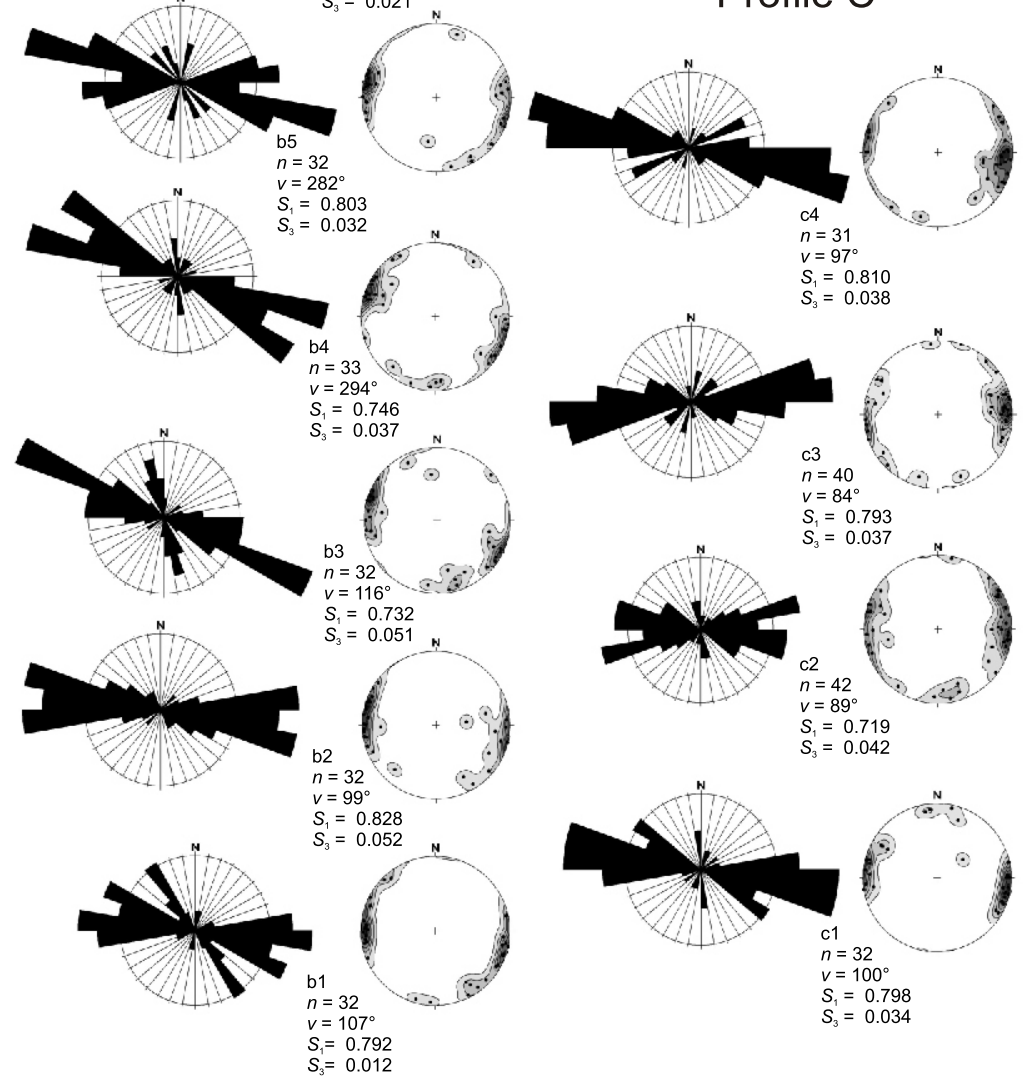

Fig. 6. Till macrofabric of the Łaziska site in vertical sections (A-C)

Location of samples in Figure 2. Note the uniform fabric within the sections. The mean vectors indicate that ice was flowing from the northern part of the Ostrava Basin towards the east, parallel to the axis of the ridge 
each other. This is a typical effect of clay deformation, which has been observed in many places in the study area where the ice sheet overrode fine-grained Neogene strata (Salamon, 2014a, 2015b). The breccia structure indicates that shear stresses were quite easily transferred from the ice sheet base into the substrate, although in fine-grained sediments such a process is not common (cf. Tulaczyk, 1999). This suggests that, at least for a short period, ice/bed coupling was quite strong From this it follows that the amount of water in the ice sheet base during this period may not have been large, despite the low permeability of the substrate, otherwise water of progressively increasing pressure would have quickly isolated the ice from the bed and restricted shear transfer to the bed (cf. Iverson et al., 1999, 2003; Fischer and Clarke, 2001). The small water content in the ice sheet base may suggest that the breccia structure could have developed during the initial phase of ice sheet overriding in the study area. However, such a structure could develop within the clay quite quickly, and so the precise determination of the time of its origin is difficult. For the same reasons, it is not possible to precisely determine the scale of the finite strain of the clayey deposits. The breccia structure may be a result of short-term deformation, and may reflect limited sediment displacement, especially in the case of the distinctly angular character of the aggregates. However, it may also effectively mask many earlier deformation episodes, if these occurred.

Shear planes superimposed on brecciated clays indicate a more brittle response of sediments to applied stress. This may suggest an increase in the shear strength of the sediments. The development of shear planes could have been promoted locally by a greater concentration of clay in some primary laminae. This conclusion refers especially to the regular, subhorizontal shear planes (Fig. 4B). Their correlation with the primary lamination suggest a rather restricted intensity of clay deformation. The timing of shear plane development is also difficult to establish. It may be related to a much later phase when the clays were overlain by till. However, the only confident assertion is that they were formed later than the breccia structure. Particularly interesting are the largest shear planes located below the till (Figs. 3C and 4A) which reflect a completely non-plastic behaviour of the clay. The failure of the sediments along a distinct decollement, located at some depth below the diamicton, may indicate a progressive stiffness of clays, which experienced stronger compaction.

The source of the gravel clasts occurring within the clays below the till is problematic in interpretation. Salamon (2015b) interpreted individual pebbles in similar positions to be the result of clasts sinking into the substrate after previously being lodged at the till/substrate contact. In this case, such an interpretation seems unlikely because the gravels form distinct concentrations or even small inclusions. Moreover, although a glacial origin of gravels cannot be excluded, the lack of northern material within these deposits does not favour such an interpretation. In turn, the highly-rounded clasts and dominant quartz and local sandstones may suggest that the gravel is associated with a residual Pliocene or Early Pleistocene alluvial cover deposited in front of the mountains. Remnants of such deposits are known from the fore-mountain area of Southern Poland and also from the Rybnik Plateau (Makowski, 1936; Klimek, 1972). In this case, the gravels may occur close to their original position or were transported for some distance in a subglacial deformation horizon.

The gradational lower contact of unit 1 , and numerous deformation structures such as recumbent and inclined folds, and the laminae of underlying sediments incorporated from the substrate to the till, reflect the process of subglacial shearing (cf Hart and Boulton, 1991; Hart and Roberts, 1994; Roberts and
Hart, 2005; Lee and Phillips, 2008). The laminae are the result of a strong attenuation of folds initiated at the diamicton/clay contact as a result of local compression (cf. Boulton, 1996; Boulton et al., 2001; Van der Wateren, 2002). The layered structure of the diamicton occurring above is a tectonic foliation and reflects more intense deformation in the upper part of the subglacial shear zone (Van der Wateren et al., 2000). These deformation structures reflect a vertical succession of strain typical of classic deformation till (cf. Benn and Evans, 1996; Van der Wateren et al., 2000; Van der Wateren, 2002).

Large inclusions of sands and gravelly sands that occur at the diamicton/clay contact or in the lower part of the diamicton most probably reflect deposition from subglacial flows. The inclusion infills probably record a distributed-canal drainage system, which developed at the ice sheet base (cf. Clark and Walder, 1994; Walder and Fowler, 1994; Ng, 2000; Salamon, $2015 b)$. The canal sediments are deformed as a result of subglacial shearing. Folds with superimposed sets of numerous shear planes within the sands indicate the brittle-plastic nature of deformation. Quite well-preserved sandy inclusions suggest, in general, a restricted intensity of deformation and finite strain. However, silty laminae within the diamicton just above the inclusions are the result of much stronger folding and further stretching of silt folds, which were incorporated into the diamicton in the vicinity of canal lithosomes.

The deformed nature of the diamicton is consistent with the wood component within the diamicton (Fig. 4E). This material, with low resistance to glacial abrasion, is unlikely to be preserved in such good condition following very high basal friction. The inclined position of the clast also does not indicate a lodgement process from the sliding ice base. Furthermore, sets of cross-cutting grooves at the clast surface indicate at least a few episodes of clast rotation, such as is likely to have taken place within a deformation horizon. The till fabric from two lower samples of profile A may support shearing processes occurring within the till. The $S_{1}$ eigenvalues of $0.65-0.67$ indicate moderate clast arrangement, which is typical of deformation till (Dowdeswell and Sharp, 1986; Hart, 1994; Benn and Evans, 1996; Hicock et al., 1996). However, in profiles B and C fabric strength is much higher $\left(S_{1}\right.$ approx. 0.8$)$. This may indicate that deformation was spatially restricted, an interpretation that is supported by the lateral extent of unit 1 .

The massive structure of unit 2 is difficult to interpret. A lack common deformation structures and a generally high fabric strength do not indicate intense shearing in a thick deforming bed. High $S_{1}$ eigenvalues which additionally are relatively constant and vary within a small range throughout the till, may reflect a process of successive accretion of deposits merely from the thin deformation horizon (Larsen et al., 2004). This may be confirmed by a high fabric strength, which is not typical of a thick deformation till (cf. Dowdeswell and Sharp, 1986; Hart, 1994; Clark, 1997). A strong fabric would actually indicate restricted possibilities for clast rotation (cf. Hart et al., 2009). Locally, a very high fabric strength $\left(S_{1}>0.9\right)$ suggests very high strain within the ice sheet base and may indicate that sediments were lodged from a sliding ice base. Sand stringers, especially the long subhorizontal laminae, probably record subglacial water flow in a thin film along the ice/bed contact surface (Brown et al., 1987; Piotrowski and Tulaczyk, 1999; Munro-Stasiuk, 2000; Wysota, 2002; Piotrowski et al., 2006; Salamon, 2015b). This reflects very high subglacial water pressure, which was equal to or even higher than the overburden ice pressure. These conditions could have favoured basal sliding (cf. Brown et al., 1987; Piotrowski and Tulaczyk, 1999; Piotrowski et al., 2001; Narloch et al., 2012, 2013). The rarity of sandy laminae may indicate that subglacial flow through the water film occurred episodically, 

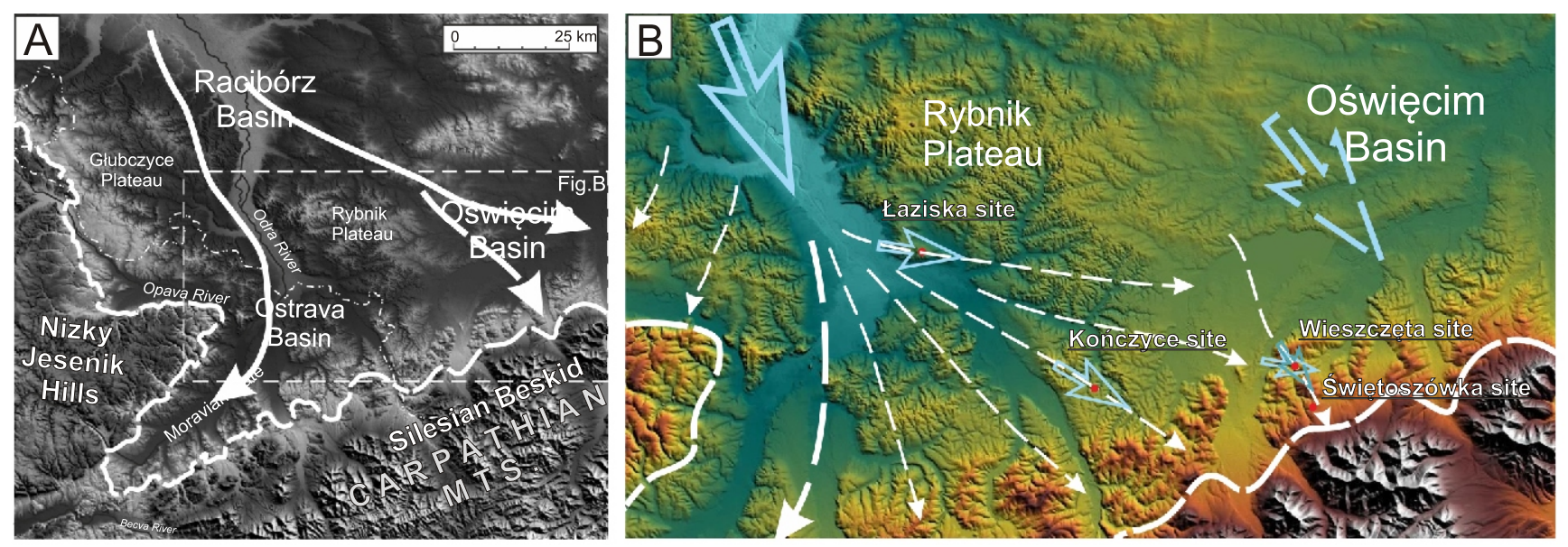

Fig. 7. Ice flow direction at the study area based on directional data from: the Łaziska site; the Kończyce site (Salamon, 2016a); the Wieszczęta site (Salamon, 2001); and the Świętoszówka site (Salamon, 2014b)

or that most of the deposits connected with such flow events are not preserved because of later shear episodes. Based on the described features, unit 2 is interpreted as traction till (Evans et al., 2006).

Unit 3 is also interpreted as a basal till. In this case, the rare silty clay laminae are particularly interesting. Most probably they are the result of deposition from suspension, from a thin column of water in subglacial cavities. They indicate temporal local separation of the ice from the bed. This process reflects a very high basal water pressure in the ice sheet base balancing overburden pressure. Conversely to the previous period, water was locally stored at the ice sheet base. Accumulation of silty clay from suspension was intermittent, with the deposition of diamictic laminae released from the ice sheet base. This type of succession, especially the well-preserved silty clay laminae, may indicate deposition during temporal ice sheet stagnation. The brecciated structure and numerous subhorizontal shear planes reflect the brittle deformation of previously deposited sediments and indicate a change of ice sheet behaviour. However, when the ice sheet was again active, its dynamics was rather restricted. Brittle behaviour of the sediments in response to the applied stress may indicate a stronger compaction of the diamicton.

\section{DEPOSITS ABOVE THE DIAMICTON}

The remainder of the succession within the Łaziska site is poorly exposed. The upper surface of the diamicton is overlain by 3-6 m of poorly-sorted sands and gravelly sands (Fig. 5C). These deposits are mostly horizontally stratified or massive (Fig. 5D). In a few places, the sands are intercalated with thin beds of diamictic sand or sandy silt. The diamictic sands or sandy diamictons up to $1.5 \mathrm{~m}$ thick occur locally above the sands (Fig. 5E). These represent glaciofluvial sediments deposited from shallow sheet flows most probably at the surface of a terminoglacial fan. The diamictic sediments were interpreted as flow tills. The whole unit was deposited after ice sheet recession and may record later ice margin oscillation or a younger (Saalian) glaciation.

\section{DIRECTIONAL DATA FROM OTHER SITES}

Directional data measured within Elsterian till are also known from a few other sites (Salamon, 2001, 2014b, 2016a). The nearest is the Kończyce site, located about $20 \mathrm{~km}$ towards the SE, a few kilometres in front of the margin of the Silesian Foothills. The ice sheet advanced over an open area of fore-mountain alluvial fan. The till from the site is characterized by very high fabric strength; $S_{1}$ is usually higher than 0.8 (Salamon, 2016a). Mean azimuths indicate ice flow direction from NW to SE (Fig. 7). Similar orientations were recorded from other kinematic structures such as folds. The Wieszczęta and Świętoszówka sites are located farther SE in the area of the Silesian Foothills (Fig. 7). Two till units reported at the Wieszczęta site are correlated with ice oscillation in the zone of the foothills margin (Salamon, 2001). Mean azimuths of clasts towards the east, within the lower till, indicate that ice flowed through the narrow valley from the larger Vistula Valley. In the upper till the clast fabric indicates a generally similar direction of ice flow, i.e. towards the SE, probably over the marginal hill of the foothills. At the Świętoszówka site, which is located much farther south, the fabric was not measured, however, mesoscale fold structures are generally oriented towards the south.

\section{DISCUSSION}

ICE FLOW DIRECTIONS

It is commonly accepted that clast orientation reflects the direction of the main stress exerted on the sediments by moving glaciers (cf. Dowdeswell and Sharp, 1986; Hicock and Dreimanis, 1992; Hart, 1994; Evans et al., 2006). A-axes of clasts are usually oriented parallel to the stress field direction (cf. Hooyer and Iverson, 2000). However, Taylor's model (1923) of clast rotation described also transverse orientation. This type of clast arrangement may occur specifically within till deposited within a compressional stress field regime (e.g., Boulton, 1970; Mark, 1974; Allen, 1984). This shows that sediment response to the applied stress may be complex (cf. Carr and Rose, 2003). More unequivocal data, which may directly indicate the direction of ice flow, is provided by kinematic structures with a distinct dip and orientation, such as recumbent folds (Van der Wateren et al., 2000). Based on the uniform orientation of till fabric and numerous kinematic structures at the Łaziska site, it can be concluded that the mean vectors of clast a-axes correspond with the main direction of the acting stress, and thus reflect real ice flow direction. All directional data from the Łaziska site indicate that ice flowed generally from the west, from the northern part of the Ostrava Basin. Such a pattern of 
flow direction is particularly important because the till is located at the top of a ridge. This indicates that ice was flowing above this elongated subglacial obstacle, parallel to its axis. The values of mean vectors vary in a very narrow range throughout the entire vertical profile of the till and indicate an almost constant direction of ice flow during progressive till accretion.

\section{SUBGLACIAL CONDITIONS AT THE CLAY RIDGE STUDIED}

The lack of large glacitectonic deformation structures and a basal till deposited generally under high basal water pressure conditions indicate that the studied ridge of the southern part of the Rybnik Plateau did not provide significant resistance for the advancing ice sheet, despite the fact that it constituted a distinct topographic obstacle. The characteristics of the ice/bed relationship were conditioned by a clayey substrate with very low permeability, which, due to a continuously high basal water pressure, restricted the transfer of shear stress to the substrate and even occasionally favoured the ice decoupling from the bed (cf. Iverson et al., 1994, 1995, 2003; Fuller and Murray, 2000). The breccia structure of the sub-till clay is somewhat exceptional, and indicates restricted water content at the ice sheet base during the first phase of ice sheet overriding the ridge studied. However, it is most likely that this episode was very short-lived. The development of the distributed-canal system evacuating excess water from the ice sheet base indicates the quick increase and release of basal water pressure. This follows from the location of sandy gravely inclusions at the diamicton/clay contact or within the lower part of the diamicton. The development of the subglacial drainage system, which efficiently reduced subglacial pore-water pressure, could have initiated the process of clay compaction as well as stiffness and subsequently brittle deformation. Shear planes within the clay reflect occasionally stronger coupling of the ice with the bed. However, rare sandy laminae and stringers within unit 2, which are correlated with flow associated with the water film, indicate that generally high basal water pressure conditions prevailed at the ice sheet base. The study case is similar to that described from another part of the Racibórz-Oświęcim Basin for the Saalian Glaciation, where a subglacial obstacle may even have favoured ice sheet sliding (Salamon, 2015b). However, in this case, episodes of ice/bed separation were less prominent.

\section{ICE DISTRIBUTION WITHIN THE MORAVIAN GATE LOBE}

Considering the fact that during the Elsterian Glaciation the ice sheet reached the margins of the Sudetes and Carpathian Mountains, it seems that the flow of the ice from north to south was generally unimpeded. However, this study indicates that after reaching a more varied substrate topography, the ice flow became more complex. The directional data collected allows a broader conclusion about the distribution of ice at the study area and in its wider vicinity. The data from the Łaziska site are particularly important. The eastern direction of ice flow indicates that ice was supplied to the study area not directly from the north, across the Rybnik Plateau, but most probably from the neighbouring Odra Valley (Figs. 7 and 8B). Such an inferred ice flow pattern suggests that this relatively narrow corridor constitutes the main transit zone of ice to the whole area of the Moravian Gate. Ice flowed through the Odra Valley probably as a narrow ice stream towards the northern area of the Ostrava Basin, from where it was further radially distributed in different directions, successively filling the morphological depression of the Ostrava Basin and later the entire Moravian Gate. The ice distribution probably was similar to that of modern piedmont glaciers, although the ice did not flow down but advanced generally over flat or a slightly reversely inclined surface. Directional data from the Kończyce site (Salamon, 2016a) indicate that ice was spreading far towards the SE (Fig. 7). It is also possible that the ice that reached the Wieszczęta site, located in the more eastern part of the Silesian Foothills (Fig. 7), also flowed over the same pathway and was supplied from the northern part of the Ostrava Basin. A divergent style of ice distribution reflects a large ice supply and suggests that ice flow through the Odra Valley could be relatively fast.

THE INFLUENCE OF THE HILLY AREA OF THE RYBNIK PLATEAU ON ICE SHEET BEHAVIOUR

The eastern direction of ice flow established at the Łaziska site shows some relationship between the topography and the pattern of ice distribution. Ice flow direction, parallel to the axis of the elongated study ridge, indicates that it did not constitute a substantial barrier for the ice sheet, which moved over the hill quite easily. Almost all the directional data indicate that ice was constantly flowing over the hill from the same direction. This specific ice flow pattern recorded at the southern margin of the Rybnik Plateau allows one to indirectly infer ice sheet dynamics for the rest of the Rybnik Plateau. This is because the subglacial conditions interpreted from the Łaziska site theoretically could also be expected at other parts of the hilly area of the Rybnik Plateau, where the till was mostly deposited over a clayey substrate. However, despite the Neogene clays of the substrate, which created high basal pressure conditions favouring rapid basal movement, the flow of the ice in this area was rather characterized by low dynamics. In this case, the ice would easily and quickly flow across the whole Rybnik Plateau from north to south. Instead, the concentration of ice flow within the Odra Valley suggests that this lowland corridor, filled with coarser grained alluvial sediments, generally produced lower flow resistance than the elevated hilly plateau composed of clays. Inferred low ice sheet mobility in much of the Rybnik Plateau area probably resulted from the fact that the more northern part of the plateau was located at a higher level $(\sim 40-50 \mathrm{~m}$ in comparison to the Łaziska site). The till within the neighbouring north palaeovalley of the Ruda River rests $>100$ m lower in comparison to the clay substrate of the highest part of the Rybnik Plateau (cf. Kleczkowski et al. 1972). Such large variations in height caused the ice to be concentrated within the surrounding valleys. The Ruda palaeovalley probably constituted the axial part of the second corridor of quickly flowing ice (Fig. 7), through which ice was distributed from the northern part of the Racibórz Basin towards the Oświęcim Basin and farther into the Carpathian Foothills.

\section{FACTORS CONTROLLING ICE DISTRIBUTION IN THE STUDY AREA}

The inferred ice flow pattern within the marginal part of the Elsterian ice sheet probably evolved over time. The heterogeneity of the ice flow resulted from stress patterns within the ice sheet, a consequence of spatially varied frictional resistance between the ice and the bed. Although the most important controlling factor was topography, a varied substrate lithology and the ice margin/permafrost relationship, which determined the strength of ice/bed coupling, may also have played a significant role (cf. Salamon, 2014a, 2015a, 2016a). If the zones that induced distinctly varied stress fields existed close to each other, then such internal ice streams could develop within the ice sheet. This hypothetical process is presented as a model in Figure 8 . It shows that, when the ice sheet reached high topo- 

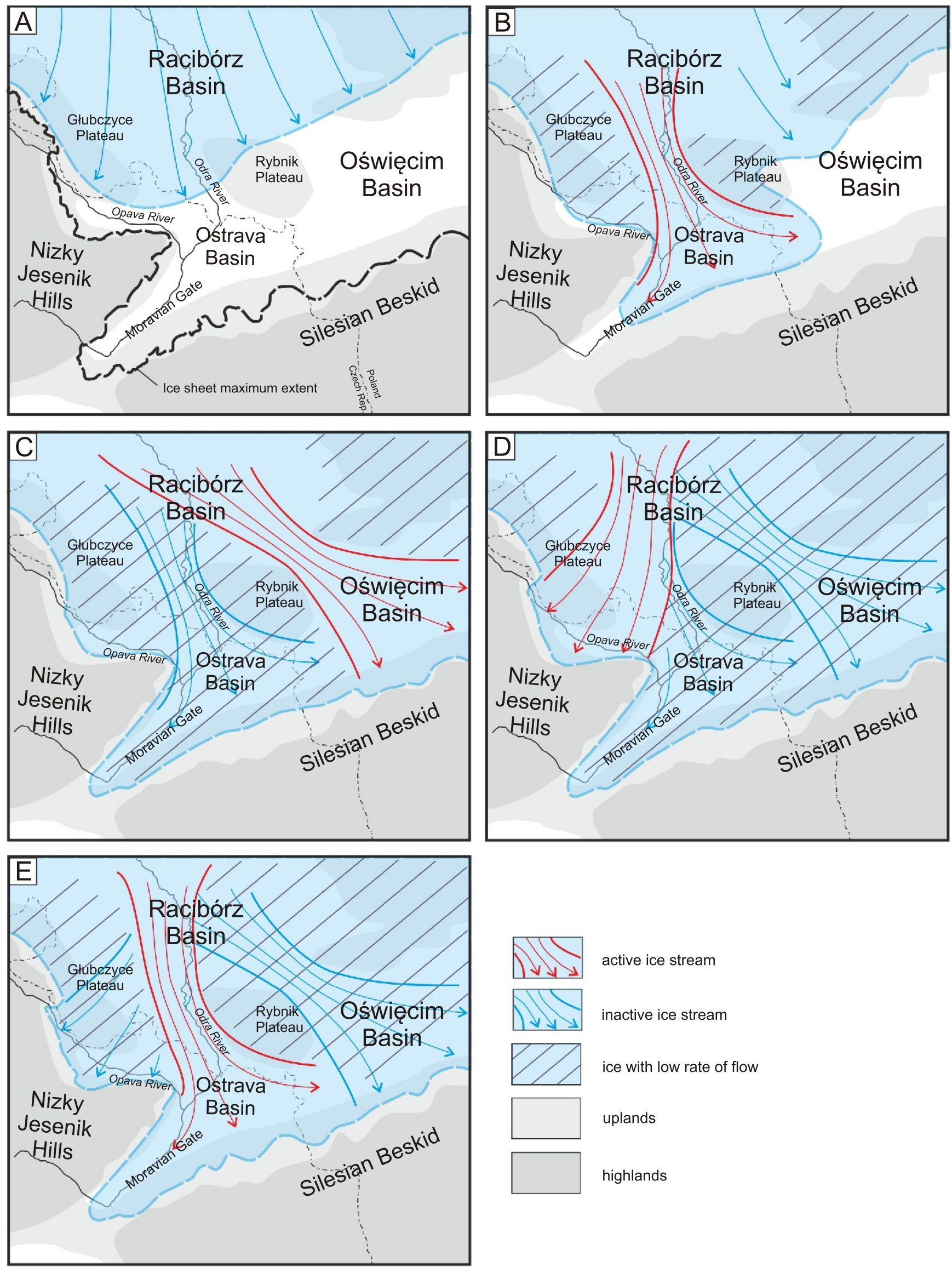

active ice stream

inactive ice stream

ice with low rate of flow

uplands

highlands

Fig. 8. Hypothetical model of ice flow distribution within the marginal part of the ice sheet in the area of the Racibórz-Oświęcim Basin and its vicinity during the Elsterian Glaciation 
graphic barriers, its flow over them towards the south was stopped for some time and became possible only after the ice reached sufficient thickness. Obstructions to ice flow behind the local barriers caused increased activity elsewhere, where the substrate generated smaller frictional resistance. The narrow zones of concentrated flow were developed in this way. This process could have occurred, for example, within the northern foreland of the Nisky Jesenik Hills (Fig. 8A, B). When the ice sheet reached this high mountain edge, further movement of ice towards the south was not possible. Increasing marginal compression most probably caused ice flow reorganization in its hinterland, and consequently, ice flow concentration within the neighbouring Ostrava Basin. This could have caused the ice sheet margin supply in the Nisky Jesenik sector to diminish, while an intense and concentrated flow of ice through the Odra Valley towards the Ostrava Basin caused the development of the Moravian Gate lobe (Fig. 8B). Similar phenomena could have occurred between the neighbouring valleys of the Odra and Ruda rivers, which were supplied by separate ice streams The topographically restricted Moravian Gate lobe, after reaching the edge of the surrounding hills, had limited possibility of further flow towards the south. As a result, the supplying ice stream could at the same time have ceased causing the enhanced activation of the Ruda ice stream, which might have become the main artery through which ice was flowing towards the large and open area of the Oświęcim Basin, and the Silesian Foothills located farther south (Fig. 8C). Moreover, a temporal lack of supply to the inactive part of the ice sheet could have induced local ice margin recession. As a result, the ice/bed relationship had to change in this area over time. This could have significantly changed the stress field within the ice sheet and thus the influence on ice flow behaviour, and even could have led to switching between adjacent streams. It is possible that the switching between neighbouring streams might have been repeated (Fig. 8C, E). There is no clear evidence for this process, though a phase of passive melting and later phase of ice sheet reactivation recorded within the upper unit of the till in Łaziska site may be consistent with this phenomenon. Multiple ice sheet readvances within the Ostrava Basin and Moravian Gate, and especially ice sheet margin oscillation within glaciotectonically deformed moraine ridges of the southern part of the Głubczyce Plateau (Opava Hilly Land; Macoun and Králík, 1995; Růžička, 2004; Nyvlt et al., 2011), may also be re- lated to this specific ice sheet behaviour governed by a complex ice/substrate relationship.

\section{CONCLUSIONS}

Study of till at the Łaziska site in the southern part of the Racibórz-Oświęcim Basin provides information about ice distribution, subglacial conditions and the dynamics of the Scandinavian ice sheet in the direct foreland of the mountains during the Elsterian Glaciation.

The sedimentological and structural features of the till indicate that relatively high basal pressure conditions occurred at the ice sheet base over the clayey ridge studied, on the southern part of the Rybnik Plateau. These conditions favoured basal mechanisms of ice sheet movement and allowed for easy ice flow over the ridge. However, the ice sheet behaviour over the rest of the Rybnik Plateau was much less dynamic.

Reconstruction of palaeo-ice flow directions indicates that the movement of the ice sheet in the area studied was complex. This resulted mainly from the fact that, before reaching the margin of the mountains of southern Poland, the ice sheet was advancing over a substrate of increasingly varied relief. Large morphological and lithological variations in the ice sheet substrate induced differential frictional resistance producing a spatially varied stress field within the marginal part of the ice sheet. This allowed the formation of passive zones of ice behind significantly large morphological barriers and active zones of streaming ice within the area, producing a distinctly lower flow resistance.

In the topographically varied area, where more than one preferential active zone of flowing ice (ice stream) occurred, local oscillation of the ice sheet margin did not have to be the result of ice sheet mass balance, but may have been the consequence of switching between neighbouring ice streams, alternately conveying ice towards the ice sheet margin. Melting of the passive ice zone and its intermittent lack of supply might have induced local recession of the ice sheet margin.

Acknowledgements. I would like to thank J. Rose and an anonymous reviewer for their helpful and constructive comments. Many thanks are addressed to T. Zieliński for discussion during preparation of the manuscript.

\section{REFERENCES}

Allen, P., 1984. Field Guide to the Gipping and Waveney Valleys. Quaternary Research Association. Cambridge.

Badura, J., Przybylski, B., 1998. Extent of the Pleistocene ice sheets and deglaciation between the Sudeten and the Silesian Rampart (in Polish with English summary). Biuletyn Państwowego Instytutu Geologicznego, 385: 9-28.

Badura, J., Przybylski, B., 2001. Problem korelacj stratygraficznych kenozoiku południowej Opolszczyzny (in Polish). VIII Konferencja: Stratygrafia plejstocenu Polski. Serie rzeczne i lodowcowe południowej Opolszczyzny. Jarnołtówek: 9-27.

Benn, D.I., Evans, D.J.A., 1996. The interpretation and classification of subglacially-deformed materials. Quaternary Science Reviews, 15: 23-52.
Boulton, G.S., 1970. Till genesis and fabric in Svalbard, Spitsbergen. In: Till: a Symposium (ed. R.P. Goldthwait): 41-72. Ohio State University Press, Columbus, $\mathrm{OH}$.

Boulton, G.S., 1996. The origin of till sequences by subglacial sediment deformation beneath mid-latitude ice sheets. Annals of Glaciology, 22:75-84.

Boulton, G.S., Dobbie, K.E., Zatsepin, S., 2001. Sediment deformation beneath glaciers and its coupling to the subglacial hydraulic system. Quaternary International, 86: 3-28.

Brown, N.E., Hallet, B., Booth, D.B., 1987. Rapid soft bed sliding of the Puget Glacial Lobe. Journal of Geophysical Research, 92: 9059-9082.

Butrym, J., Maruszczak, H., Wojtanowicz, J., 1988. Thermoluminescence chronology of the Sanian (=Elsterian) inland-ice deposits in the San and upper Dniester River basins (in 
Polish with English summary). Annales Societatis Geologorum Poloniae, 58: 191-205.

Carr, S.J., Rose, J., 2003. Till fabric patterns and significance: particle response to subglacial stress. Quaternary Science Reviews, 22: $1415-1426$.

Clark, P.U., 1997. Sediment deformation beneath the Laurentide Ice Sheet. In: Late Glacial and Postglacial Environmental changes: Quaternary, Carboniferous-Permian, Proterozoic (ed. I.P. Martini): 81-97. Oxford University Press, New York.

Clark, P.U., Walder, J.S., 1994. Subglacial drain age, eskers and deforming beds beneath the Laurentide and Eurasia ice sheets. GSA Bulletin, 106: 304-314

Czubla, P., 2013. Analiza frakcji $>20 \mathrm{~mm}$ w glinie ze żwirowni w Mokrzeszowie (in Polish). XX Konferencja Stratygrafia Plejstocenu Polski, Plejstocen przedpola Sudetów Środkowych, Lasocin: 171-174.

Dowdeswell, J.A., Sharp, M.J., 1986. Characterization of pebble fabrics in modern terrestrial glacigenic sediments. Sedimentology, 33: 699-710.

Drozd, M., Trzepla, M., 2006. Szczegółowa mapa geologiczna Polski w skali 1: 50 000, ark. Zabełków (in Polish). Państwowy Instytut Geologiczny, Warszawa.

Evans, D.J.A., Phillips, E.R., Hiemstra, J.F., Auton, C.A., 2006. Subglacial till: formation, sedimentary characteristics and classification. Earth-Science Reviews, 78: 115-176.

Eyles, N., Eyles, C.H., Miall, A.D., 1983. Lithofacies types and vertical profile models; an alternative approach to the description and environmental interpretation of glacial diamict and diamictite sequences. Sedimentology, 30: 393-410.

Fischer, U.H., Clarke, G.K.C., 2001. Review of subglacial hydro-mechanical coupling: Trapridge Glacier, Yukon Territory, Canada. Quaternary International, 86: 29-43.

Fuller, S., Murray, T., 2000. Evidence against pervasive bed deformation during the surge of an Icelandic glacier. Geological Society Special Publications, 176: 203-216.

Hanáček, M., Nývlt, D., 2009. Subglacial gravely tills from Jindrìichov in the Osoblaha Spur. Časopis Slezského Zemského Muzea, Opava (A), 58: 193-214.

Hart, J.K., 1994. Till fabric associated with deformable beds. Earth Surface Processes and Landforms, 19: 15-32.

Hart, J.K., Boulton, G.S., 1991. The interrelation of glaciotectonic and glaciodepositional processes within the glacial environment. Quaternary Science Reviews, 10: 335-350.

Hart, J.K., Roberts, D.H., 1994. Criteria to distinguish between subglacial glaciotectonic and glaciomarine sedimentation: I. Deformation styles and sedimentology. Sedimentary Geology, 91: 191-213.

Hart, J.K., Rose, K.C., Martinez, K., Ong, R., 2009. Subglacial clast behaviour and its implication for till fabric development: new results derived from wireless subglacial probe experiments. Quaternary Science Reviews, 28: 597-607.

Hicock, S.R., Dreimanis, A., 1992. Deformation till in the Great Lakes regions: Implications for rapid flow along the south-central margin of the Laurentide Ice Sheet. Canadian Journal of Earth Sciences, 29: 1565-1579.

Hicock, S.R., Goff, J.R., Lian, O.B., Little, E.C., 1996. On the interpretation of subglacial till fabric. Journal of Sedimentary Research, 66: 928-934.

Hooyer, T.S., Iverson, N.R., 2000. Clast-fabric development in a shearing granular material: implications for subglacial till and fault gouge. GSA Bulletin, 112: 683-692.

Iverson, N.R., Jansson, P., Hooke, R., Le, B., 1994. In situ measurement of the strength of deforming subglacial sediment. Journal of Glaciology, 40: 497-503.

Iverson, N.R., Hanson, B., Hooke, R.L., Jansson, P., 1995. Flow mechanism of glaciers on soft beds. Science, 267: 80-81.

Iverson, N.R., Baker, R.W., Hooke, R.LeB., Hanson, B., Jansson, P., 1999. Coupling between a glacier and a soft bed: I. A relation between effective pressure and local shear stress determined from till elasticity. Journal of Glaciology, 45: 31-40.
Iverson, N.R., Cohen, D., Hooyer, T.S., Fischer, U.H., Jackson, M., Moore, P.L., Lappegard, G., Kohler, J., 2003. Effects of basal debris on glacier flow. Science, 301: 81-84.

Jahn, A., 1952. The profile of the Pleistocene deposits in Góry Kęckie near Kety (Carpathians) (in Polish with English summary). Biuletyn Państwowego Instytutu Geologicznego, 65: 467-477.

Karaś-Brzozowska, C., 1963. Limit of the Middle-Polish (Saale) glaciation in the Racibórz Basin (in Polish with English summary). Przegląd Geograficzny, 35: 431-446.

Kleczkowski, A.S., Dendewicz, S., Dyjor, J., Kowalski, J., Miłkowski, M., 1972. Pliocene-Quaternary Rybnik-Koźle Trough and its hydrogeological properties. Bulletin de l'Academie Polonaise des Sciences, Série des Sciences de la Terre, 20: 71-83.

Klimaszewski, M., 1952. The problems of the Pleistocene in Southern Poland (in Polish with English summary). Biuletyn Państwowego Instytutu Geologicznego, 65: 137-268.

Klimek, K., 1972. Kotlina Raciborsko-Oświęcimska. In: Geomorfologia Polski, 1 (ed. M. Klimaszewski): 116-138. PWN, Warszawa.

Kotlicka, G.N., Kotlicki, S., 1979. Mapa geologiczna Polski w skali 1: 200 000, ark. Gliwice. Wyd. Geol., Warszawa.

Krzyszkowski, D., Ibek, M., 1996. Middle Pleistocene sedimentation and palaeogeography of the Dzierżoniów Basin, Sudetic Foreland, Southwestern Poland. Annales Societatis Geologorum Poloniae, 66: 35-58.

Krzyszkowski, D., Karanter, R., 2001. Glacial sediments and palaeogeography of the northwestern foreland of the Mount Ślęża massif, Southwestern Poland. In: Late Cainozoic Stratigraphy and Palaeogeography of the Sudetic Foreland (ed. D. Krzyszkowski): 109-145. WIND, Wrocław.

Larsen, N.K., Piotrowski, J.A., Kronborg, C., 2004. A multiproxy study of a basal till: a time-transgressive accretion and deformation hypothesis. Journal of Quaternary Science, 19: 9-21.

Lee, J.R., Phillips, E.R., 2008. Progressive soft sediment deformation within a subglacial shear zone - a hybrid mosaic-pervasive deformation model for Middle Pleistocene glaciotectonised sediments from Eastern England. Quaternary Science Reviews, 27: $1350-1362$

Lewandowski, J., 1988. Middle Pleistocene in the upstream Odra valley region: Moravian Gate - Racibórz Basin (synthetical approach) (in Polish with English summary). Przegląd Geologiczny, 36: 465-474.

Lindner, L., 2001. Problems of the age and extent of the Scandinavian glaciations at the margin of the Polish Carpathians (southern Poland) (in Polish with English summary). Przegląd Geologiczny, 49: 819-821.

Łanczont, M., 1997. Profile of the Quaternary deposits at Siedliska (Foreland of the Przemyśl Carpathians, south-eastern Poland) and its paleogeographic aspect. Studia Geomorphologica Carpatho-Balcanica, 30: 5-29.

Macoun, J., Králík, F., 1995. Glacial history of the Czech Republic. In: Glacial Deposits in North-East Europe (eds. J. Ehlers, S. Kozarski and P.L. Gibbard), 389-405. A.A. Balkema, Rotterdam-Brookfield.

Makowski, A., 1936. Sprawozdanie z badań geologicznych w 1935 r. w zachodniej części arkusza Gorzyce mapy Polskiego Zagłębia Węglowego w skali 1:25 000. Posiedzenia Naukowe Państwowego Instytutu Geologicznego, 45: 1-4.

Mark, D.M., 1973. Analysis of axial orientation data, including till fabrics. GSA Bulletin, 84: 1369-1374.

Mark, D.M., 1974. On the interpretation of till fabrics. Geology, 2: 101-104.

Marks, L., 2005. Pleistocene glacial limits in the territory of Poland. Przegląd Geologiczny, 53: 988-993.

Mojski, J.E., 2005. Ziemie polskie w czwartorzędzie (in Polish). Zarys morfogenezy. Państwowy Instytut Geologiczny, Warszawa. 
Munro-Stasiuk, M.J., 2000. Rhythmic till sedimentation: evidence for repeated hydraulic lifting of a stagnant ice mass. Journal of Sedimentary Research, 70: 94-106.

Narloch, W., Piotrowski, J.A., Wysota, W., Larsen, N.K., Menzies, J., 2012. The signature of strain magnitude in tills associated with the Vistula Ice Stream of the Scandinavian Ice Sheet central Poland. Quaternary Science Reviews, 57: 105-120.

Narloch, W., Wysota, W., Piotrowski, J.A., 2013 Sedimentological record of subglacial conditions and ice sheet dynamics of the Vistula Ice Stream (north-central Poland) during the Last Glaciation. Sedimentary Geology, 293: 30-44.

Ng, F.S.L., 2000. Canals under sediment-based ice sheets. Annals of Glaciology, 30: 146-152.

Nitychoruk, J., 1991. Glacial deposits of the Tarnów Plateau (S Poland) and the problem of Dunajec outflow during the San II (= Elsterian II) glaciation. Annales Universitatis Mariae Curie-Skłodowska Sectio B Geographia, Geologia, Mineralogia et Petrographia, 46: 187-200.

Nývlt, D., Engel, Z., Tyráček, J., 2011. Pleistocene glaciations of Czechia. Development in Quaternary Science, 15: 37-46.

Piotrowski, J.A., Tulaczyk, S., 1999. Subglacial conditions under the last ice sheet in northwest Germany: ice bed separation and enhanced basal sliding. Quaternary Science Reviews, 18 737-751.

Piotrowski, J.A., Mickelson, D.M., Tulaczyk, S., Krzyszkowski, D., Junge, F., 2001. Were subglacial deforming beds beneath past ice sheets really widespread? Quaternary International, $\mathbf{8 6}$ 139-150.

Piotrowski, J.A., Larsen, N.K., Menzies, J., Wysota, W., 2006. Formation of subglacial till under transient bed conditions: deposition, deformation, and basal decoupling under a Weichselian ice sheet lobe, central Poland. Sedimentology, 53: 83-106.

Roberts, D.H., Hart, J.K., 2005. The deforming bed characteristics of a stratified till assemblage in north East Anglia, UK: investigating controls on sediment rheology and strain signatures. Quaternary Science Reviews, 24: 123-140.

Růžička, M., 2004. The Pleistocene glaciation of Czechia. Development in Quaternary Science, 2: 27-34.

Salamon, T., 2001. Sedimentary succession and morphologic control of glaciomarginal paleogeography in the foothill area, an example from the Silesian Beskid (Poland). Studia Geomorphologica Carpatho-Balcanica, 35: 39-61.

Salamon, T., 2014a. Basal till and subglacial conditions at the base of the Upper Odra ice lobe (southern Poland) during the Odranian (Saalian) Glaciation. Geological Quarterly, 58 (4): 779-794.

Salamon, T., 2014b. Evolution of the glaciomarginal zone in the Silesian Beskid foothill (Bielsko division of the Silesian Foothills) (in Polish with English summary). Przegląd Geologiczny, 62 103-110.

Salamon, T., 2015a. Development of the topography-controlled Upper Odra ice lobe (Scandinavian Ice Sheet) in the fore-mountain area of southern Poland during the Saalian glaciation. Quaternary Science Reviews, 123: 1-15.

Salamon, T., 2015b. Sedimentary record of a Scandinavian Ice Sheet drainage system and till deposition over subglacial obstacles promoting basal sliding (an example from southern Poland). Sedimentary Geology, 330: 108-121.

Salamon, T., 2016a. Subglacial conditions and Scandinavian Ice Sheet dynamics at the coarse-grained substratum of the fore-mountain area of southern Poland. Quaternary Science Reviews, 151: 72-87.

Salamon, T., 2016b. Reply to comment by D. Nývlt on "Development of the topography-controlled Upper Odra ice lobe (Scandinavian Ice Sheet) in the fore-mountain area of southern Poland during the Saalian glaciation". Quaternary Science Reviews, 133: $185-187$.

Salamon, T., Wójcik, A., 2010. Development of a fore-mountain alluvial fan of the Olza River (southern Poland) during the Pleistocene. Annales Societatis Geologorum Poloniae, 80: 39-52.

Taylor, G.I., 1923. The motion of ellipsoidal particles in a viscous fluid. Proceedings of the Royal Society of London, Series A 103: $58-61$.

Tulaczyk, S., 1999. Ice sliding over weak, fine-grained tills: dependence of ice-till interactions on till granulometry. GSA Special Paper, 337: 159-177.

Tyráček, J., 2011. Continental glaciation of the Moravian Gate (Czech Republic). Journal of Geological Sciences, Anthropozoic, 27: 39-49.

Van der Wateren, F.M., 2002. Processes of glaciotectonism. In: Modern and Past Environments (ed. J. Menzies). Butterworth and Heinemann, Oxford: 417-443.

Van der Wateren, F.M., Kluving, S.J., Bartek, L.R., 2000. Kinematic indicator of subglacial shearing. Geological Society Special Publications, 176: 259-278.

Walder, J.S., Fowler, A., 1994. Channelised subglacial drainage over a deformable bed. Journal of Glaciology, 40: 3-15.

Wojtanowicz, J., 1985. The TL dated profile of the Quaternary deposits at Giedlarowa (Sandomierz Basin) and its paleogeographic importance (in Polish with English summary). Studia Geomorphologica Carpatho-Balcanica, 19: 37-44.

Wójcik, A., 2003. Quaternary of the western part of the Jasło-Sanok Depression (Polish Outer Carpathians) (in Polish with English summary). Prace Państwowego Instytutu Geologicznego, 178: $1-148$.

Wójcik, A., Nawrocki, J., Nita, M., 2004. Pleistocene in the Kończyce profile (Oświęcim Basin) - sediment genesis and age analysis at the background of stratigraphic schemes of the Quaternary (in Polish with English summary). Biuletyn Państwowego Instytutu Geologicznego, 409: 5-50.

Wysota, W., 2002. Stratigraphy and sedimentary environments of the Weichselian Glaciation in the southern part of the Lower Vistula River (in Polish with English summary). Wydawnictwo Uniwersytetu Mikołaja Kopernika, Toruń. 